\title{
Article \\ No Country for Muslims? The Invention of an Islam Républicain in France and Its Impact on French Muslims
}

\author{
Nina Käsehage (D)
}

check for updates

Citation: Käsehage, Nina. 2022. No Country for Muslims? The Invention of an Islam Républicain in France and Its Impact on French Muslims.

Religions 13: 38. https://doi.org/ $10.3390 /$ rel13010038

Academic Editors:

Anastasia Mitrofanova and

Sharyl Cross

Received: 4 October 2021

Accepted: 20 December 2021

Published: 31 December 2021

Publisher's Note: MDPI stays neutral with regard to jurisdictional claims in published maps and institutional affiliations.

Copyright: (C) 2021 by the author. Licensee MDPI, Basel, Switzerland. This article is an open access article distributed under the terms and conditions of the Creative Commons Attribution (CC BY) license (https:// creativecommons.org/licenses/by/ $4.0 /)$
Department of Religious Studies and Intercultural Theology, Faculty of Theology, University of Rostock, 18055 Rostock, Germany; nina.kaesehage@uni-rostock.de

\begin{abstract}
Since the beheading of the French teacher Samuel Paty on 16 October 2020, the call for a fight against the so-called 'Political Islam' has been heard once again, not only in France, but all over Europe (EU). The politicization of Islam is held to be responsible for the increasing attacks by radical Islamic actors within European metropoles, and the EU states' call for action and revenge in response to this ideology and its adherents, in order to guarantee public security and democratic values. Starting from the major terrorist attacks in France in the last few years, this paper seeks to compare the interlinking between domestic policy and religious radicalization and its impact on neighboring states. With regard to the attacks on 13 November 2015 in France, the attackers were traced back to radical networks in Belgium and Germany. Based on selected interviews that have been conducted by the author with female adherents of jihadist milieus within the years 2015 and 2016 in France and social media examples of Muslim reactions on the current French law enforcement, the tension between domestic policy and religious freedom related to Islam in France will be highlighted in this article. Among other reasons, the interview quotations and social media reactions can be seen as a result of a specific religious understanding and practice related to Islam by some actors. In addition, the ongoing othering of Muslims by France and other European societies can be seen to be in sum to be responsible for the increasing interest of young Muslims in radical Islamic thought that led to jihadist attacks within France in the not-so-distant past. With respect to the aforementioned development, this article will conceptualize the problematique of a (politically motivated) category formation related to one religion that is currently practiced in France, as seen from the perspective of a religious studies scholar.
\end{abstract}

Keywords: category formation; human rights; politicization of religion; Islam Républicain; Laïcité; political Islam; religious studies; secularization of Islam; secularization of religion; religion and security

\section{Introduction}

On 16 October 2020 the French teacher Samuel Paty was beheaded within public view at Conflans-Sainte-Honorine, a suburb of Paris, by an 18 year old French pupil with Chechen roots (FAZ 2020). It is reported that the perpetrator wanted to set an example on behalf of Islam by killing the 47 year old French teacher who encouraged his students to question religious content, including Islamic matters, during his lessons in light of the right to freedom of speech that is guaranteed in public schools in France (cf. RFI 2020).

This incident can be seen in line with various attacks that were motivated by radical Islamic actors and groups which had taken place in Belgium, France and Germany in the last few years. Examples for this development are the five terrorist attacks that took place in the 10th and 11th arrondissements in Paris and in three places in the suburb Saint-Denis on 13 November 2015 (Seelow 2021), the two bombings on 22 March 2016 in Brussels (s. Higgins and Freytas-Tamura 2016) and the truck attack on 19 December 2017 in Berlin (cf. Biermann and Thurm 2018). At first sight, it would seem that these attacks could have 
taken place at random. At second glance, further similarities between these incidents are uncovered:

(1) A number of attackers were part of the Moroccan migrant communities in the three concerned countries and were familiar with each other or their families.

(2) Some of them had a criminal past, ${ }^{1}$ before they turned to the jihadist interpretation of Islam and went abroad to join the former Islamic State (IS) where a few of them had been part of the same battle units or in contact with leaders of battle branches. ${ }^{2}$

(3) All of the perpetrators had been part of an active European network of jihadists with strong ties to Brussels (in particular Molenbeek).

(4) All of the targets attacked may be seen as symbols of Western society, for instance a nightclub (Bataclan) in Paris, a football-arena in St. Denis, a metro station (Maelbeek) close to the European Union's headquarters and the international airport in Brussels and a Christmas market in Berlin (cf. Buchanan and Park 2016).

With respect to the increase of global terrorist attacks caused by militant jihadist actors and groups, the search for local and national reasons regarding the aims of this development becomes more and more crucial (cf. Downing 2020). This article therefore focusses on a possible link between the alienation of Muslim citizens in France through legislative measures and other governmental approaches and their vulnerability to Islamic radicalization as their reaction to ongoing anti-Islamic racism in France. ${ }^{3}$ Belgium and France have been especially affected to a larger extent by jihadist attacks by actors who have had close ties. Therefore, it is possible that domestic policies in France and the close ties between French and Belgium jihadists, their common familial connections or heritage, and their negatives experiences as 'second class citizens' in combination could be responsible for their affiliation to radical Islamic groups and content (cf. Downing 2020).

The governmental attempt to secularize Islam highlights the active role of a Western democracy regarding discrimination toward one religion (cf. Cesari 2013b), though this endeavor could not be observed in terms of other religions in Belgium, France or Germany thus far. Noteworthy information regarding this development is for instance provided by the books 'State, Religion and Muslims' (Saral and Baheçecik 2020, esp. chapter 2 by Brems that deals with anti-Muslim discrimination in Belgium (Brems 2020), 'Governing Muslims and Islam in Contemporary Germany' (Aguilar 2018) and 'Unveiling the French Republic: National Identity, Secularism and Islam in Contemporary France' (Nilsson 2018)). One of their common findings is the fact that Belgium, French and German Muslims are suffering from an alienation of both their religion and their belonging to Islam - that includes their individual right to religious belief and practice-to a certain extent.

Given the above, this contribution focusses on France and its policy towards Muslims in order to exemplify a possible connection between religiously motivated attacks by militant Islamic milieus that may be seen in light of other European cities, and a lack of integration of Muslim citizens into these Western societies (cf. Cesari 2013a). Through selected interviews that were conducted with French female members of jihadist movements by the author, and examples of media reactions of young French Muslims regarding the current French domestic policy towards Muslims, the overall question considered is whether the lack of equality regarding Muslims and their religion and the attempt of European countries such as France to re-cast Islam in order to regulate Muslim citizen's faith, could be in combination responsible for the increasing jihadist movements and attacks that have taken place within France and other European countries (cf. Sèze 2008, 2015, 2019a, 2019b). ${ }^{4}$

\section{Methodology}

The present research results are partially based on a media analysis regarding Muslim reactions in view of anti-Islamic legislation within France, and partly build on selected interviews of a sample with ten French female jihadists (aged 18-23). These interviews are part of a larger sample of 65 interviews in total that were conducted by the author in the framework of her qualitative religious research in nine European countries' jihadist milieus between the years 2012 and 2017. Access to the concerned female actors was ensured by 
snowball sampling among the European jihadist milieu. It is important to point out that although all of the concerned French interview partners had been members of the local jihadist milieu, they were not automatically part of the militant jihadist milieu. To grasp that conceptual difference is important, because belonging to a group whose members might cognitively 'support' the use of violence to enforce their religious or political goals, will not necessarily lead them to do that in practice as well. The terrorism expert Peter Neumann of the King's College London visualizes the need to distinguish between these two jihadist groups with his concept of the cognitive extremists and the ready to use violence extremists (cf. Neumann 2013, pp. 3-7). According to Neumann, cognitive extremists do not necessarily transform to ready to use violence extremists and become terrorists, but are willing to use their belonging to a cognitive extremist group as a valve function. With his theory, Neumann contradicts the so-called frontline assembly theory that is based on the assumption that cognitive extremism unavoidably leads to ready to use violence extremism (Neumann 2013 , p. 6). In that sense, this article will visualize this distinction of the interviewed female members of the French jihadist milieu by highlighting their heterogeneous attitudes towards topics such as, for instance, French citizenship or their individual understanding of gender roles.

With respect to the mistrustful jihadist environment where the admission to females was even more difficult for a researcher than in view of the mostly publicly already wellknown male actors, it was important to ensure privacy to the interviewees in the light of scientific ethics and individual reliability (cf. Käsehage 2017, pp. 41-44). Additionally and against the background of the young age of most of the female interviewees, it was necessary to anonymize their names in order to enable them a possible future re-start in the event they might have left the jihadist scene on reaching their adulthood (Käsehage 2018, p. 21). Therefore, they will be called 'Umm' (Arabic: mother of) and a fictive name that was given to them in order to guarantee their anonymity.

The focus of the present paper relies on the results of the media analysis and selected interviews regarding the following topics: the self-perception as a (female) Muslim and French citizen (1), their individual interpretation of Islam (2), their attitude towards violence (3) and the perception of their own sex and role within French society (4). With the help of selected quotations from both sources the overall question regarding the impact of the French domestic policy in terms of their Muslim citizens and Islamic radicalization will be discussed and certain issues highlighted. The results concerning the situation of French Muslims exemplify the current conditions and individual needs of young Muslims in one European country that might be co-responsible for their search of belonging and their rebellion towards the state. They could be useful in view of the prevention of Islamic radicalization (cf. Jackson 2014) in France and other countries with a similar domestic policy towards Muslims.

\section{Discussion of the Systematical Framework}

\subsection{Category Formation of Religion within Democracies}

In the course of the aforementioned rise of radical Islamic movements in France and their impact on both French citizens and citizens of neighboring countries such as Belgium, the French government has been concerned about the loss of democratic structures and values within their country (cf. Doyle 2013). As one of various approaches, France tried to shape its citizens' understanding as anti-democratic tendencies of radical religious movements and political concepts. With the help of specific terms, the government tried to address possible threats related to extremist movements and to highlight the importance of national political concepts through a common political wording. This wording was then multiplied by the government, corresponding political platforms, and news agencies. As a result of this category formation, terms such as 'Political Islam' were constructed and defined as movements whose leading actors are interested to 'use' the religion Islam in order to mobilize its adherents for their political goals in France and other European countries (cf. Cesari 2018, 2020a; cf. Roy 1992). Regardless of the fact that in some cases this 
development could be reported in view of specific Islamic Unions (cf. Martinez 2016), from the perspective of a religious scholar, the attempt of an executive power like a national government that tried to pare down the religious freedom of one religious community is more salient for the present paper. This governmental behavior underlines the attempts of a democracy to mark out a possible national enemy by highlighting it with the help of specifically constructed terms. This act of politicization of a whole religion can be seen as domestic policy through linguistics. If only a European 'version' of Islam seems to be accepted by or rather be suitable for French or other EU governments, what does this tell us about the political structures and concepts of these countries and their democratic aims to guarantee and protect the religious freedom of each of their citizens? Is the French laïcité not capable of tolerating individual Islamic religious practice (cf. Kelly 2017)? What impact does the politicization of Islam in France have on French Muslims: will they become second class citizens? Do Muslims have to decide themselves between their belonging to a nation and their individual right to believe in a specific faith and will there be a distinction between 'good' and 'evil' Muslims directed by the state (cf. Käsehage 2021, p. 305)? These starting considerations will be exemplified in view of Muslims who live in France against the background of fundamental democratic rights such as religious freedom and the freedom of opinion or expression, that are also their human rights.

Though it is not possible here to offer an Islamic theological discussion about the concept of for instance an EURO-Islam such as Tibi (2009) suggested, the endeavor of France to fragment Islam in favor of its governmental objectives and to create national versions, e.g., a French or republican Islam such as "Islam de France" (cf. Raymond 2009) or "Islam républicain" (Sèze 2019b, p. 171; cf. Sèze 2015, pp. 43-58) is highly questionable though it contains the possibility of mantling anti-Islamic resentments and interfering with individual faith that is a private affair (cf. Riedel 2007).

\subsection{Secularism vs. Religious Freedom}

According to Jocelyne Cesari, the "nation state" is a "secular political project that has transformed all religious debates for individuals and for society." (Andre 2017, pp. 68-69). Although religion is seen today as a private matter because of Western Europe's history, voices occurred that question its limitation to the private sphere, for instance in view of certain religious clothes requirements such as the hijab (veil) (cf. Andre 2017; cf. Doyle 2011). For Cesari, secular cultures are represented by "secular justification, collective versus individual rights and embodied religious practices that are all tested by the Muslim demands." (Cesari 2020b, p. 4)

With respect to these considerations regarding the legislation of religious freedom and the institutionalisation of religion within European democracies, "formal agreements of cooperation between religious institutions and the state exist" in Belgium and Germany whereas France follows the concept of laïcité (cf. Roy 2005b; cf. Adnani 2018) that is based on the strict separation of "the state and religious institutions" (Cesari 2020b, p. 3; cf. de Wit 2014). In view of laïcité, Hauser points out that "today's laizité [ ... ] [p]assed in the heated atmosphere of the Dreyfus Affair, anti-Semitism, and ideological struggles between secularist republicans and conservative Catholic nationalists, the 1905 Law ended the Concordate system, removed Catholicism from its favoured position, and inaugurated the modern French secular era." (Hauser 2021, p. 150). According to Downing (2019) “France has faced a number of critiques in its attempts to assimilate Muslims into an ostensibly secular (but predominantly Catholic) state and society". Legal manifestations related to the French discrimination of its Muslim citizens could for instance be observed since the 1980s in France (cf. El Hamel 2002; cf. Hauser 2021) and in terms of French laws of the years 2004 ('Headscarf law') and 2010 ('Burqa Ban') (cf. Asad 2006; cf. Weill 2006; cf. Hancock 2008; cf. Adrian 2009; cf. Croucher 2009; cf. Barras 2010; cf. Hancock 2015; cf. Hancock and Mobillion 2019; cf. De Galembert and Raillard 2014, cf. Adam-Troiän et al. 2019). The provision of religious education ${ }^{5}$ in the public space is practiced on the basis of state requirements that lead to the development of Muslim organizations who negotiate this 
cooperation in France and Belgium (Cesari 2020b, p. 3). In France, critique occurred related to the relationship of schools and laïcité that was observed to be linked with Muslim and gender-based discrimination towards (female) believers (Hauser 2021, pp. 152, 155; cf. Limage 2000; cf. Teeple Hopkins 2015; cf. Hancock and Mobillion 2019; cf. Lizotte 2020).

In 2013, Armando Salvatore, a professor of Global Religious Studies at McGill University, pointed out, that

"the vulnerable presence of Islam in Europe is not merely yet another problem in the historic dealing with religion in the Old Continent, but plays a strategic role in questioning post-Christian tenets of the secular and the related concepts of solidarity and immunity, both pivoting on sovereignty. Islam in Europe can expose the inherent contradictions and weaknesses of European secular models issued of early modern traumas and transformations and the parochial limitations of secular arrangements between churches and states going back to the nineteenth and twentieth century." (Salvatore 2013, p. 63).

Salvatore's reflections regarding the secularization in Europe is based on the historical development of relations between the Christian churches and the nation state that may be seen as the foundation of the current 'legitimation' of Europe's discrimination of religions other than Christianity:

"The case of Islam's presence in Europe generates tensions that show ever more clearly how the post of post-Christian regimes does not mean the overcoming of Christian tenets and Westphalian strictures, but their dilution into the presuppositions of life forms themselves, via the entrenchment of a juridical doctrine of the sacredness of individual, and in this sense autonomous, life projects." (Salvatore 2013, p. 63).

This aspect is also raised by Tariq Modood, a Professor of Sociology, Politics and Public Policy and founding Director of the Centre for the Study of Ethnicity and Citizenship at the University of Bristol, in view of the impact of the Anglican Church on British politics as a result of their common history. (Modood 2021, p. 8.). According to his own faith-based perspective as a Muslim, Modood does not argue against a religious influence on secular politics, but calls for the "share [of the] constitutional privileges" of the Church of England with other religions (namely Islam and its British Muslim representatives) to value the growing number of British Muslims in terms of a "multiculturalized Britain" (Modood 2021, p. 8.; cf. Modood 2005, 2013). His plea for a change of secularism in favour of Islam

"distinguish[es] between the separation of church and state based on religious freedom in the United States (US), a French-style marginalization of organized religion in the public space and, [ ... ] the dominant mode of political secularism in Western Europe. I call this 'moderate secularism' and [ ... ] it does not consist of a separation of religion and the state. It in fact includes state recognition of and state support for religion-for example, all the states of the European Union (EU), including France, fund specific faith schools or teach specific Christian faiths in state schools-but insists that religious authority must not control political authority. In giving primacy to liberal democratic constitutionalism it marries a conception of religious freedom with an understanding that religion can be a public good - or harm — and that the state may need to assist it in achieving that good [ ... ]. I argue that Muslims can be and should be accommodated within moderate secularism; and to do so is to achieve an egalitarian integration, a multiculturalized secularism." (Modood 2021, pp. 2-3).

In contrast to Modood, Cesari stated that "scholars of religion have demonstrated that ethno-religious recognition has little influence on the restrictive interpretation of secular principles. From this perspective, it is important to distinguish between ideological conceptions of secularism ${ }^{6}$ and secularity as a set of principles embodied in laws." (Cesari 2020 b, p. 3). According to her, Modood neglects other factors such as "legal and institutional 
conditions" that could lead to a "discrimination of Muslims": "scholarship on secularism, [... ] usually refers to the legal status of religious organisations as well as state-religion relations but not specifically to the individual's religious rights." (Cesari 2020b, p. 3). Modood's "ethno-religious model" could lead to an "entrapping of Muslims in ethnicity with the risk to play into the hands of external political forces, and isolating them further from possible religious allies in the mainstream society." (Cesari 2020b, p. 3).

\section{Empirical Analysis}

\subsection{The Concept of an Islam Républicain and Its Consequences for France and Its Muslim Citizens}

Islam is the second largest religious community in France and the largest Muslim community in Europe (cf. Yeung 2021). Nevertheless, many French Muslims have the impression that they are alienated and often discriminated in public without consequences for anti-Islamic offenders.

The essay by Hauser (2021) 'Education, secularism, and illiberalism: Marginalisation of Muslims by the French State' of the University of Cambridge, based on qualitative interviews with French Muslim students of higher education, demonstrates various forms of discrimination and othering of French Muslims, for instance in view of the secular schools and its impact on gendered islamophobia, on behalf of laïcité.

With respect to the concerned group of French female jihadists, that is part of the present article, the impression of being 'othered' as Muslims in France can be confirmed with the help of their individual statements:

"I'm treated like a foreigner ${ }^{7}$ in Paris although this is my home-town. Elderly people turn their faces off me when I cross the streets and some of them spit out and mock about my hijab." (Umm Aylia 2015, p. 1. See Appendix A)

"I'm a French. This is my country. My grandparents came from Morocco to France and opened a few shops for vegetables. My parents work there and I work there, too. We pay the tax like every other French, but we are treated like fools ('Nulls'). It hurts me to see my grandmother treated like a dog because she wears the face veil. They can hurt me, I know how to defend myself, but she is quiet. She would never raise her voice against her attackers. It feels that I have to decide between my nation and my faith and this is not fair." (Umm Mustafa 2016, p. 1.)

Both interviewees were members of a jihadist movement in France. While Umm Aylia could participate occasionally at public lectures of jihadist preachers with her older brother, Umm Mustafa radicalized herself through the reading of jihadist online postings of French Muslims who went to Syria and joined IS. Both young women declared that they agree on the religious interpretation of Islam by jihadists because "it fulfils my heart with pride to be a Muslim women" (Umm Mustafa 2016, p. 3) and "gives me the feeling that we will no longer suffer this injustice [in France] in silence, cause our time will come." (Umm Aylia 2015, p. 2).

With respect to the question, how they would estimate the use of violence based on their Islamic interpretation, e.g., in view of a change of the current political climate (in the years 2015/16) in the world or particularly in France, their answers differed a lot. While Umm Aylia seems to struggle with an answer regarding this question-waging "religious arguments for and against a jihad" (Umm Aylia 2015, p. 7) [in this context understood as the militant form of it], leaves Umm Mustafa's response no doubt about her positioning towards the use of violence:

"Our time has come. The true Islam will rule the world! It started in Shams [Syria] but it will come to Europe sooner than you might think. [..] Violence, what is violence for the West? An instrument to keep us Muslims small and exploit our earth treasures. It is foreseen [in the Qur'an] that the true believers will win the final battle towards the infidel. You will see!" (Umm Mustafa 2016, p. 8.) 
The different perceptions of two female members of the two different French jihadist environments regarding the Islamic assessment of the use of violence towards non-believers reflect the heterogeneity of the jihadist milieu in France and in view of its members. Although many French jihadists went abroad to join the militant jihad in Syria (cf. Thomson 2016), others remained at home and disagreed with IS' cruelty because it would not mirror the Islam that "I am used to." (Umm Aylia 2015, p. 9.). Although Umm Aylia's brother was educated with the same Islamic values like his sister, he "becomes more and fascinated by IS" (Umm Aylia 2015, p. 9.) whereas his sister refused their religious interpretation. Although these two examples of female jihadists only reflect a small part of the whole jihadist scene (cf. Khosrokhavar 2003), it might nevertheless be suitable to underline the diverse French jihadist milieu that demands a differentiated view and not one generalized treatment that should fit each of its 'members'.

\subsection{The 'Anti-Separatism' Bill}

After the deadly attack on Samuel Paty, the French President Emmanuel Macron stated in October 2020 that "Islam is a religion which is experiencing a crisis today, all over the world", and calls to "free Islam in France from foreign influences" (Macron cited after Yeung 2021). This statement from the head of a country indicated two things: the loss of objectivity of the French President towards a whole religion and his unwillingness or rather inability to differentiate between radical Islam actors and groups and the worldwide majority of peaceful Muslims. Additionally, it seems questionable, that a religion such as Islam that was not originating from France as a religion, could be separated from its 'foreign' roots that reflects the diversity and the heritage of its believers. Should a European politician 'dare' to assess a crisis related to a whole religion, while the reasons of young vulnerable people to join jihadist movements in Europe and esp. in France (cf. Khosrokhavar 1997; cf. Kepel 2005) can be found in the ongoing alienation of Islam and the discrimination of Muslim citizens (cf. König 2016)? According to the well-known French scholar Olivier Roy, an expert in the field of Islamic radicalization, "[a]nother cliché is that Muslims do not condemn terrorism. But the Internet is overflowing with condemnations and anti-terrorist fatwas." (Roy 2015). So why were they not considered in view of political speeches or in terms of legal debates?

Critique towards the political stigmatizations of French Muslims occurred for instance already in 2019 when more than 13,000 French citizens gathered for a march against existing Islamophobia in Paris, claiming that French Muslims are proud to be both Muslims and French citizens, demanding a stop to their further alienation as 'undesired persons' (cf. Chambraud 2019).

Instead of reflecting about more adequate possibilities to prevent the development of jihadist ideas in the heads and hearts of young French (Muslims), France passed the so called 'anti-separatism' bill in August 2021 (RFI 2021). The term is based on the concept of "Islamist separatism" - a chiffre for Jihadist terrorism and Islamic extremism-that was defined as the ideology of "the enemy of the Republic" France (Yeung 2021). The Interior Minister of France, Gérald Darmanin, called the launch of the bill "excellent news for the Republic" and assumed that "it would help President Emmanuel Macron's administration to fight against those who want to undermine secularism." (RFI 2021). The anti-separatism' bill contains 51 articles and contains law enforcement regarding online hate speech and "separatism" offences in particular towards "elected official or public sector employee[s]" with high imprisonment penalties and monetary punishments (Yeung 2021):

"The bill extends what is known in France as the "neutrality principle", which prohibits civil servants from wearing religious symbols like the Muslim hijab and voicing political views, beyond public sector employees to all private contractors of public services such as those working for transport companies." (Yeung 2021)

Although the latest attacks in France indicate an increase of radical and violence prone actors in the French jihadist milieu (e.g., Chapuis and Vincent 2019; Thomson 2016, Kepel 2015) and makes decisions regarding this dangerous development reasonable, it 
might be wise to search for more tailored and 'case-by-case' decisions instead of general verdicts about all French Muslims. It should not be forgotten that there were also a lot of Muslim victims of the terrorist attacks (cf. Roy 2015). The bill seems to protect in particular representatives and employees of the French state. But if Muslims could not achieve these professions due to their deprivation as members of Islamic communities (cf. Kepel 1987, 2012), the vicious cycle of anti-Muslim racism and radical Islamic radicalization will not end in France (cf. Cesari 2011).

In addition, it should be pointed out that the majority of French Muslims comply with the values of the secular state, work for the state themselves or lost their lives while defending French democracy for instance such as police officer Ahmed Merabet who was killed when trying to stop the attackers of the Charlie Hebdo offices, as pointed out by Roy (2015) in his article named "There Are More French Muslims Working for French Security Than for Al Qaeda". In accordance with Roy, it must be criticized that "[i]nstead of being cited as examples, they are considered counter-examples", because [t]he "real" Muslim is said to be the terrorist and the other are the exceptions" although "statistically, this is false: in France, there are more Muslims in the army, the police, and the gendarmes than in the Al Qaeda network, not to mention in government administration, hospitals, law practices." (Roy 2015).

Many non-governmental and other initiatives in France and abroad called the bill a way to "single[s] out the minority Muslim population" (Roy 2015) More than "100 imams, 50 teachers in Islamic sciences and 50 presidents of associations in France [ ... ] signed an open letter against the "unacceptable" charter on February 10 [2021]." (Roy 2015) This diverse protest among France against the bill should be suitable to visualize the seriousness of the nationwide concerns regarding the legal and state-related discrimination of one group in France.

\subsection{The Hijab Ban}

According to several scholars, the discussion about the veil functions in France as a proxy debate over the role of laïcité' in terms of the individual, the community and the identity politics towards the French state's values (cf. El Hamel 2002; cf. Jansen 2006; cf. Werbner 2007; cf. Baubérot 2009) Teeple Hopkins calls this French Muslim misogyny a sexist Islamophobia (cf. Teeple Hopkins 2015).

A contemporary political approach of the French Senate related to the veil was the attempt "to ban girls under 18 from wearing the hijab in public" (Al Jazeera 2021) in the year 2021. This repeated intervention in the individual freedom of female Muslims has caused critics by various groups, of whom many agreed with "the hashtag \#HandsOffMyHijab circulating widely on social media" (Al Jazeera 2021). According to Al Jazeera (2021), "[t]he hijab is a headscarf worn by many Muslim women and has been the subject of a decades-long feud in France."

"On Instagram, Olympic athlete Ibtihaj Muhammad shared a post suggesting the Senate's amendment indicated "Islamophobia is deepening in France". "This is what happens when you normalize anti-Islamic and anti-Muslim hate speech, bias, discrimination, and hate crimes-Islamophobia written into law," the post said." (Al Jazeera 2021) It was liked 227,609 times (see Figure 1). 


\section{The Senate in France has voted:}

-No girl under the age of 18 can wear a hijab 2 in public, AND;

-Mothers with hijab \& cannot accompany their kids on school trips

Islamophobia is deepening in

\section{France.}

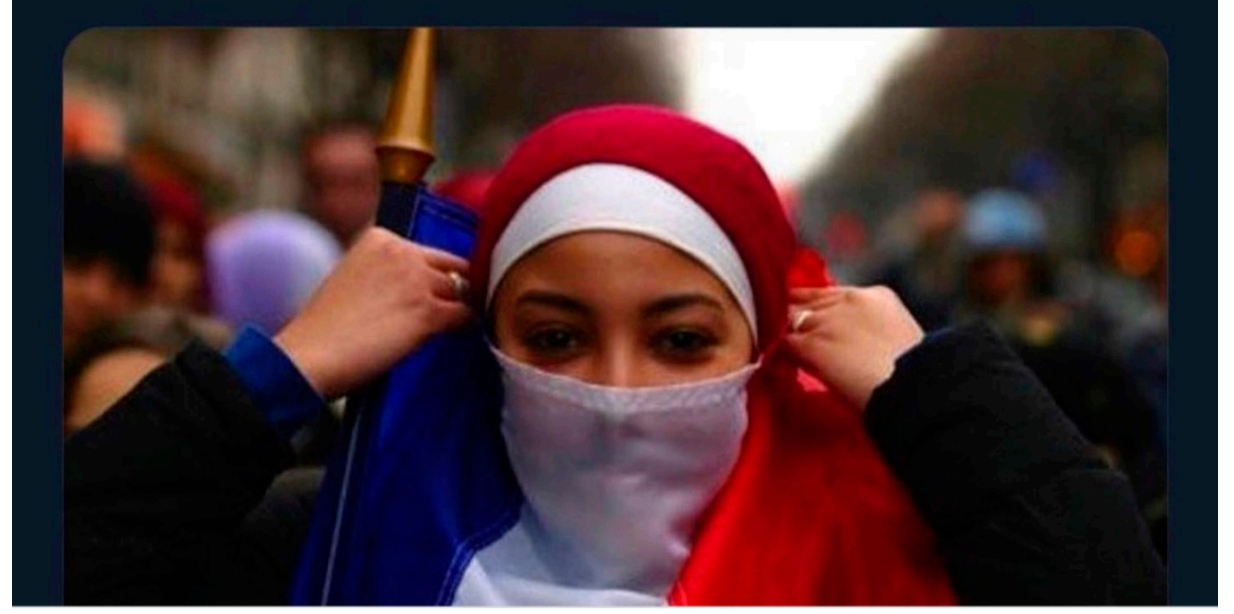

Figure 1. Posting of Ibtihaj Muhammad on Instagram cited after Al Jazeera (2021). ${ }^{8}$

With respect to the increasing protest towards the hijab ban, domestic policies regarding personal rights are compared: "Age to consent to sex in France: 15 Age to consent to hijab: 18."(comment, cited after Al Jazeera 2021).

\subsection{Gendered Islamophobia}

According to Hauser, "[i]n particular, existing research demonstrates that Muslim women represent a gendered and radicalized category in the eyes of the French state as a consequence of laïcité (Hauser 2021, p. 151). As aforementioned, since the 1980s discussions arose in France regarding the individual freedom of decision-making that have been fueled again with the current legal attempt by France to ban the hijab: "Forcing a woman to wear a hijab is wrong. Just like forcing her to take it off is wrong. It's HER choice." (Al Jazeera 2021). Again the old attempt to interlink radical Islamic content with female's clothing choices (cf. Carland 2011) occurred in a Western society although there is no evidence that women who wear veils could be held responsible for many terrorist attacks in the West so far. ${ }^{9}$ The call of legislation related to women's bodies as a consequence of these incidents, uncovers a deep masculine thinking pattern that still solely women are held responsible for children's education-and in view of French Muslims, held responsible for children's Islamic knowledge, which is assumed to be militant because of their mother's hijabs. This interlinking copies old-fashioned education expectations and is not suitable for 21st century 
democracies. Ironically, it repeats expectations of fundamentalist Islamic groups related to children's education.

Subsequently, French female Muslims question gender equality within France such as "Somali-born model Rawdah Mohamed [who] suggested the French Senate's move had put it on "the wrong side of equality". (Al Jazeera 2021). "The Hijab ban is hateful rhetoric coming from the highest level of government and will go down as an enormous failure of religious values and equality." (Al Jazeera 2021) (see Figure 2).

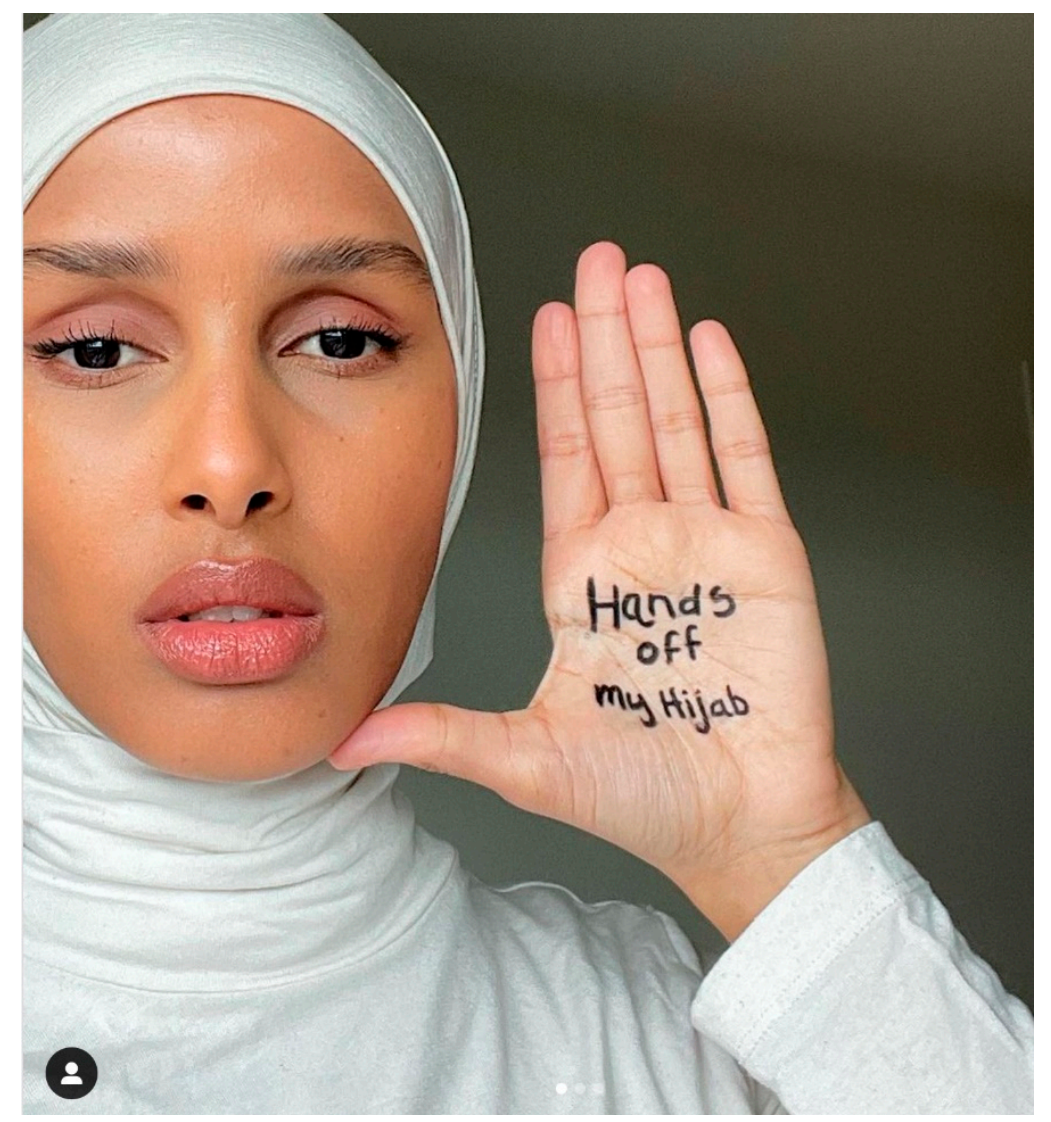

Figure 2. Posting of rawdis on Instagram cited after Al Jazeera (2021). ${ }^{10}$

The perception of their own sex and role within the French society has also been raised by several female members of jihadist groups in France that are part of the author's qualitative data. Several interviewees did not understand why their individual decision for virginity was questioned by French authorities in public:

"I thought it is my decision to decide whether I want to sleep with a man or not. Is it my body or a property of France?" (Umm Ayoub 2016, p. 3)

"If I say in public, I want to marry and to become a housewife and care about my husband and my children, people look at me like I am an alien. [ ... ] Why shall I wear short skirts, show my hair and look like a cheap slut like my student's colleagues-only to get credits from them? I hate their appearance and the way they put pressure on girls to wear make-up and high heels in public. I will dress up for my husband's eyes only. It is solely his right to see me like this." (Umm Talib 2016, p. 5).

The aforementioned selected quotations of the interviews with female members of French jihadist groups and the examples of media reactions of French Muslims regarding law enforcements related to their religion, underline the imbalance of French legislative and government to judge actions related to anti-Islamic racism ${ }^{11}$ in the same extent as they do 
in view of jihadist and anti-Laïcité activities. This double-standard related to human-rights highlights an ongoing discrimination of Muslims in France (cf. the same pattern in view of England: s. Modood 2005).

The attempt of reshaping Islam by inventing a national version of it that is based on "new Islamic institutions and representatives" (Cesari 2020b, p. 3), touches the integrity of a whole religion and is unacceptable from a constitutional perspective, it damages the individual right of religious freedom.

It is questionable, why the three European countries are only willing to cooperate with representatives of the so-called liberal or mainstream Islam when the majority of their Muslim citizens has individual religious affiliations with conservative or even fundamentalist Islamic unions. There should be no automatic equation of terrorist, violent or rather anti-democratic tendencies of Muslims who belong to Islamic communities that follows fundamentalist interpretations of Islam though religious fundamentalism is not equal to terrorism as we can see in view of the United States of America where the Evangelists-who represent a major Christian group in the US - strictly follow the five fundamental tenets of their religion (cf. Deen Larsen 2005; cf. Kienzler 2007).

\section{Conclusions}

With respect to the discussed considerations regarding the use(-lessness) of the creation of an Islam "made in France" and the aims and limits of secular societies in comparison to individual human rights, the main concern in this context must be the question whether Europe's understanding of diversity includes tolerance towards various forms of Islamic communities. If so, it should be no problem for European countries such as France to tolerate numerous shades of Islam, Islamic practice and individual Islamic faith. In contrast to the European claim for the protection of religious freedom of each citizen, the present article visualized that a country such as France, with an old European tradition, shows ongoing issues regarding the acceptance of an un-uniform Islam that does not correspond with its national values. According to Roy, "Muslims are criticized for being a community, but then asked to react against terrorism as a community. This is called the double bind: be what I ask you to be." (Roy 2015). Roy calls the juxtaposition of this bias attitude a "deadlock" and demands "to first take into account a number of inescapable facts-facts which we do not want to acknowledge because they show us that the radicalized young people are in no way the vanguard or the spokesmen of the Muslim population, and in particular, that there is no "Muslim community" in France." (Roy 2015).

Although the discussion has shown that the governmental concerns regarding militant Islamic groups in France are the result of ongoing jihadist attacks in the country occurring from within the jihadist milieu, they seem not to be capable of seeing that their law enforcement, in order to prevent further attacks and to bring back respect towards French officials, public authorities and certainly in view of French national values, are too generally framed and too sweeping in scope. In their ambition to protect the French nation, it appears that President Macron and his colleagues attack all Muslim citizens by comparing them with terrorists and making them all suffer for the individual actions of some violent persons. The inability to accept different forms of Islamic schools and traditions will show in the long-term if the current governmental measurements are successful, or lead to further radicalization and protest in the underground movements. If Europe itself is diverse, why does it seem to be so hard for the French state to accept the same diversity in view of its Muslim citizens and their religious practices? Against the background of Europe's anti-Semitic history, it might be wise for France to avoid repeating the same patterns by establishing laws that could be perceived as anti-Islamic racism (Jikeli 2018, p. 103; cf. Bayrakli and Hafez 2019, p. 12).

Common legal and moral values that should unite France are expressed within its own Code Civil (French legislation). There is no doubt, that these values build the framework wherein French citizens can create their lives, work, build their families and follow their religious practices. France provides a large space for its citizens' individuality that is seen 
as one of its greatest strengths in comparison to authoritarian states. At the same time, this advantage could become its largest disadvantage in terms of these groups and actors who try to stretch the limits of the possible. As in other European countries, France too is challenged by anti-Semitic, misogynist, homophobic and violence-related content and goals of groups and individuals who live under its protection and threaten others with their narrow-minded worldviews (cf. Gutton 2015; cf. Khosrokhavar et al. 2015). Though all individuals are living under the same umbrella of democracy, they all deserve to be protected against ideologically or religiously motivated attacks.

The freedom of speech is a basic law in France. It allows French citizens to have their individual opinions $^{12}$ and the maxim of religious freedom enables believers to follow their individual understanding, e.g., related to good and evil, wearing of specific clothes and gender roles. Voltaire (1764) said: "C'est clair que tout particulier qui persécute un homme, son frère, parce qu'il n'est pas de son opinion, est un monstre."13

In this sense, all individual or religion-related understandings regarding a faith-based life must be accepted-no matter if the majority in a society dislikes them-if they do not lead to the suppression of other individuals. That is what we might call a living example of democracy and its values.

From the perspective of a religious studies scholar, the complexity of every religion must be guaranteed within the framework of a democracy. If someone does not hurt or discriminate against others' rights by believing in a certain religious paradigm, he/she/it cannot be forced to believe in other religious values only because the state wants him/her/it to do so. That would not reflect the expression of religious freedom but a governmental attempt to claim power and control over one's individual faith (on the French attempt to homogenize Muslim citizens see for instance Roy 2005a; cf. Vanparys et al. 2013). Against the background of democratic values, this would be a demand that cannot be agreed with-under any circumstances. History has shown us what happened to individuals that were subjugated to one worldview: they became living puppets of dictators and lost their freedom, individuality, and in the end their lives. Therefore, it is an unjustifiable discrimination if countries such as France try to impose the view that only a 'French Islam' is acceptable (cf. Raymond 2009; cf. Adam-Troiän et al. 2019). The launching of the 'separatism bill' is just the latest example in a row of fundamental mistakes made by the French state regarding its Muslim citizens that might generate further hatred, mistrust and in the end Islamic radicalization (cf. Khosrokhavar 2014) as reactions of the ongoing anti-Islamic discrimination practiced in France (Bayrakli and Hafez 2019, p. 12). According to Van der Made (2021), "[t]he bill also triggered unusually critical coverage in Englishlanguage media, even prompting French President Emmanuel Macron to write personally to the Financial Times to defend it, stating that "France is against 'Islamist separatism'never Islam." Analysts stated that the French President, "who came to power in 2017 as a centrist reformer, has noticeably veered to the right over the last months as he recognizes that his 2022 presidential reelection battle will come down to a run-off duel with the far-right Le Pen." (Van der Made 2021; cf. McLaughlin 2019).

The French state's claims to re-create a national Islam and to regulate individual faith is going too far, it is beyond European democratic values and it shows an unequal legal treatment regarding one religion in comparison to other religions, for instance Christianity, that also exhibits fundamentalist tendencies in France (cf. Ménudier 2014). With respect to Goldberg (2006), Hauser (2021) stated

"In France, Muslims represent this 'sacrificial stranger' who are seen as needing assimilation to comply with a standard norm of Frenchness deriving from national parochialisms that presume Europeans to be White Christians. Literature has demonstrated that this assimilationist paradigm has a tendency to homogenise Muslim populations-despite their ethnic, racial, and cultural diversity-as a singular outsider who needs to continually assimilate [ . . ], in a process that Grillo (2004) refers to as 'transethnicization', where Muslims from diverse 
backgrounds are amalgamated into a singular musulmam français community." (Hauser 2021, p. 151).

Regardless of the fact how many individuals blame their violent behavior towards others or their participation in extremist attacks on their Islamic faith instead of their individual attraction for violence, it is no excuse for a state to use the same lame excuse for their own attempt to breach the law in view of all members of one religion. This behavior cannot be glossed-over with the reference that some Muslims might be responsible for this approach, because the responsibility of a state has to be settled on a higher level. If a state would step back from its own responsibility for anti-discrimination and uses the biblical rhetoric of 'an eye for an eye', it loses its claim of representing democratic values and will follow the rule of shari'a laws of an Islamic State where 'a tooth for a tooth' justifies the crime of one person towards another by equalizing them through another crime and injustice.

Furthermore, the claim of some European countries for nationalist versions of Islam only repeats the authoritative demand of radical Islamic individuals or groups related to their inclusive interpretation of Islam. From the perspective of a religious studies scholar, it can be stated that one religion Islam exists, but a lot of individual interpretations of it are possible. ${ }^{14}$ So why should France retreat from this scientific interpretation regarding Islamic plurality?

Funding: This research received no external funding.

Institutional Review Board Statement: The qualitative interviews that are part of this article were conducted in accordance with the declaration, Forschungsethische Grundsätze und Prüfverfahren in den Sozial- und Wirtschaftswissenschaften'of the Rat für Sozial- und Wirtschaftsdaten (RatSWD), 9. Output, 5. Prüfungsperiode, funded by the Federal German Ministry for Science and Research (Bundesministerium für Bildung und Forschung), Berlin, July 2017. doi:10.17620/02671.1.

Informed Consent Statement: Informed consent was obtained from all subjects involved in the study.

Data Availability Statement: Not Applicable.

Conflicts of Interest: The author declares no conflict of interest.

\section{Appendix A}

Interviews with French female jihadists that have been conducted by the author in France in the years:

2015.

Umm Aylia (19 years old), pp. 1-10.

2016.

Umm Ayoub (19 years old), pp. 1-11.

Umm Mustafa (18 years old), pp. 1-10.

Umm Talib (20 years old), pp. 1-12.

\section{Notes}

1 For instance Abdelhamid Abaaoud, Ibrahim Abdeslam, Ibrahim and Khalid el-Bakraoui spent time in Belgium and French prisons together (s. Buchanan and Park 2016; cf. Khosrokhavar 2013).

2 Bilal Hadfi, a French citizen living in Belgium and one of the stadium attackers in St. Denis, was in contact with the branch leader of Kattibat al-Battar al-Libi in Syria, Abdelhamid Abaaoud via Facebook (s. The New York Times 2015).

3 According to Jikeli (2018), 676 anti-Islamic actions have been recorded in 2018 by the Collectif contre l'islamophobie en France (CCIF). This is an increase of anti-Islamic incidents of 52\% since the year 2017 (p. 103; cf. De Lorenzo 2021 in view of Belgium).

4 This aspect might also be of interest in view of other European countries. With respect to the required extent of the present contribution, its discussion will be limited to selected examples of the three mentioned countries.

5 According to Ghosh et al. (2016), an appropriate school subject regarding 'Islamic religion' could also be useful in terms of the prevention of Islamic radicalization. 
6 The discussion about the concepts of secularity and secularism could certainly be practiced to a larger extent, for instance from the perspective of political scientists. In the present paper, they are just explained generally though they function only as the political framework that might be a trigger for radical Islamic ideas and the development of radical Islamic milieus that are the main research interests of this contribution.

7 Highlighted words express the emphasis of the concerned word that was expressed during the interviews.

8 “Law against Islam': French vote in favour of hijab ban condemned". Al Jazeera, 9 April 2021. (https://www.aljazeera.com/ news/2021/4/9/a-law-against-islam). Accessed on 3 September 2021.

9 According to Perry (2013), the majority of anti-Islamic incidents in France have been directed to Muslim women as a result of a "Gendered Islamophobia".

10 Posting of rawdis on Instagram cited after Al Jazeera (2021). "Law against Islam': French vote in favour of hijab ban condemned". Al Jazeera, 9 April 2021. (https:/ / www.aljazeera.com/news/2021/4/9/a-law-against-islam). Accessed on 3 September 2021.

11 Critics regarding the neutrality of the French state arose in the course of the so called 'Mila affair'. The 16 year-old school girl insulted the religion Islam and its deity Allah on social media and received over 100,000 hate messages in 2020. 11 individuals have been convicted over harassing the girl online. This cases causes a national discussion about the freedom of speech "including the right to use blasphemy against religions, which is protected by French law." (Durie 2021). The French President Macron defended this law by saying: "We have the right to blaspheme, to criticize and to caricature religions." (Durie 2021).

Current French restrictions may be seen in view of the French emergency law (law 2015-1501) that was established in France since 14 November 2015 until 15 June 2017 as a result of the terrorist attacks and constituted state interventions regarding the constitutional freedom of French citizens (cf. Jobard 2017).

13 The author's own English translation of it: "It is clear that an individual who persecutes another, his brother, because he does not share his opinion, is a monster."

14 In view of the various facets of Islamic religious practices and traditions are certainly more aspects available and to be mentioned, for instance from the perspective of an Imam or an Islamic theologist. Unfortunately, this information cannot be covered in the present contribution.

\section{References}

Adam-Troiän, Jäis, Thomas Arciszewski, and Themis Apostolidis. 2019. National identification and support for discriminatory policies: The mediating role of beliefs about laïcité in France. European Journal of Social Psychology 49: 924-37. [CrossRef]

Adnani, Mazika. 2018. Le rôle de l'Etat n'est pas de réformer l'islam, mais de protéger la laïcité. Le Monde. December 18. Available online: https: / / www.lemonde.fr/idees/article/2018/12/18/razika-adnani-le-role-de-l-etat-n-est-pas-de-reformer-1-islammais-de-proteger-la-laicite_5399039_3232.html (accessed on 19 December 2018).

Adrian, Melanie. 2009. France, the Veil and religious freedom. Religion, State and Society 37: 345-74. [CrossRef]

Aguilar, Luis Hernández. 2018. Governing Muslims and Islam in Contemporary Germany. Race, Time, and the German Islam Conference. Muslim Minorities. Leiden: Brill, vol. 26.

Al Jazeera. 2021. Law against Islam': French vote in favour of hijab ban condemned. Al Jazeera. April 9. Available online: https:/ / www.aljazeera.com/news/2021/4/9/a-law-against-islam (accessed on 3 September 2021).

Andre, Virginie. 2017. Conference Report: Addressing the New Landscape of Terrorism: Towards Formulating Actionable Response. Paper presented at the 2nd International Conference "Addressing the New Landscape of Terrorism: Towards Formulating Actionable Response", Bangkok, Thailand, July 24-27; pp. 1-172.

Asad, Talal. 2006. Trying to understand French secularism. In Political Theologies. Edited by Hent de Vries and Lawrence E. Sullivan. New York: Fordham University Press, pp. 494-526.

Barras, Amélie. 2010. Contemporary laïcité: Setting the terms of a new social contract? The slow exclusion of women wearing headscarves. Totalitarian Movements and Political Religions 11: 229-48. [CrossRef]

Baubérot, Jean. 2009. Laïcité and the challenge of 'republicanism'. Modern E Contemporary France 17: 189-98.

Bayrakli, Enes, and Farid Hafez. 2019. The State of Islamophobia in Europe in 2018. In Islamophobia Report 2018. Edited by Enes Bayrakli and Farid Hafez. Istanbul: SETA.

Biermann, Kai, and Frieda Thurm. 2018. Acht Ungereimtheiten im Fall Amri. Zeit Online. January 31. Available online: https: //www.zeit.de/politik/deutschland/2018-01/amri-untersuchungsausschuss-bundestag-fragen (accessed on 22 November 2021).

Brems, Eva. 2020. Discrimination against Muslims in Belgium. In State, Religion and Muslims. Between Discrimination and Protection at the Legislative, Executive and Judicial Levels. Edited by Melek Saral and Şerif Onur Baheçecik. Muslim Minorities. Leiden: Brill, vol. 33, pp. 65-108.

Buchanan, Larry, and Haeyoun Park. 2016. Uncovering the Links Between the Brussels and Paris Attackers. The New York Times. April 9. Available online: https://www.nytimes.com/interactive/2016/03/23/world/europe/how-the-brussels-and-paris-attackerscould-be-connected.html (accessed on 28 September 2021).

Carland, Susan. 2011. Islamophobia, fear of loss of freedom, and the Muslim woman. Islam and Christian-Muslim Relations 22: 469-73. [CrossRef] 
Cesari, Jocelyne. 2011. Islamophobia in the West: A Comparison between Europe and the United States. In Islamophobia. The Challenge of Pluralism in the 21st Century. Edited by John L. Esposito and Ibraim Kalin. Oxford: Oxford University Press, pp. $21-43$.

Cesari, Jocelyne. 2013a. Self, Islam and Secular Public Spaces. In Islam and Public Controversy in Europe, 1st ed. Edited by Nilüfer Göle. London: Routledge, pp. 47-57.

Cesari, Jocelyne. 2013b. Why the West Fears Islam: Exploration of Muslims in Liberal Democracies. New York: Palgrave Macmillan.

Cesari, Jocelyne. 2018. What Is Political Islam? Boulder: Lynne Rienner Publishers.

Cesari, Jocelyne. 2020a. Religion, State and Nation: Islamic Parties between Ideology and Religion. In The Routledge Handbook to Religion and Political Parties, 1st ed. Edited by Routledge. London: Routledge, pp. 20-30.

Cesari, Jocelyne. 2020b. Secularism Versus Multiculturalism. Identities, Global Studies in Culture and Power 28: 1-6. [CrossRef]

Chambraud, Cécile. 2019. Plus de 13000 personnes marchent à Paris contre la stigmatization des Français de confession musulmane. Le Monde, November 10.

Chapuis, Nicolas, and Elise Vincent. 2019. Attaque a la Prefecture de Police: La Radicalisation de Mickael Harpon n'avait pas ete Signalee. Le Monde. October 7. Available online: https://www.lemonde.fr/societe/article/2019/10/07/la-radicalisation-demickaelharpon-n-avait-pas-ete-signalee_6014525_3224.html (accessed on 22 November 2021).

Croucher, Stephen M. 2009. French-Muslims and the Hijab: An Analysis of Identity and the Islamic Veil in France. Journal of Intercultural Communication Research 37: 199-213. [CrossRef]

De Galembert, Claire, and Sarah-Louise Raillard. 2014. Forcing the law to speak out against the Burqa: Judicial Politics à la Française? Revue Française de Science Politique 64: 17-38.

De Lorenzo, Daniela. 2021. 2016 Brussels attacks: On anniversary, Muslims remain stigmatised. Al Jazeera. March 22. Available online: https: / / www.aljazeera.com/news/2021/3/22/in-brussels-muslim-woman-rally-together-to-confront-islamophobia (accessed on 16 September 2021).

de Wit, Theo W. A. 2014. Laicite: French secularism and the turn to a postsecular society. Telos 2014: 143-61. [CrossRef]

Deen Larsen, Max. 2005. Amerikanischer Fundamentalismus. Eine Einführung. In Religiöser Fundamentalismus. Informationen-Analysen. Edited by Grete Anzengruber and Elke Renner. Innsbruck, Wien and Bozen: Schulbuch, Issue 30, pp. 47-71.

Downing, Joseph. 2019. French Muslims in Perspective: Nationalism, Post-Colonialism and Marginalization under the Republic. Cham: Palgrave Macmillan.

Downing, Joseph. 2020. Confronting orientalism, colonialism and determinism. De-constructing contemporary French jihadism. In Exporting Global Jihad. Critical Perspectives from Africa and Europe. Edited by Tom Smith and Solomon Hussein. London: I.B. Tauris \& Co Ltd., vol. 1, pp. 157-74.

Doyle, Natalie J. 2011. Lessons from France: Popularist anxiety and veiled fears of Islam. Islam and Christian-Muslim Relations 22: 475-89. [CrossRef]

Doyle, Natalie J. 2013. Islam, Depoliticization and the European crisis of democratic legitimacy. Politics, Religion E Ideology 14: 265-83.

Durie, Alexander. 2021. Free speech vs. Islamophobia: A teenager fuels debate in France. Al Jazeera. August 10. Available online: https: / / www.aljazeera.com/news/2021/8/10/mila-affair-free-speech-islamophobia (accessed on 14 September 2021).

El Hamel, Chouki. 2002. Muslim Diaspora in Western Europe: The Islamic Headscarf (Hijab), the Media and Muslims' Integration in France. Citizenship Studies 6: 293-308. [CrossRef]

FAZ. 2020. Nach Attentat auf Lehrer: Sieben Festgenommene vor Anti-Terror-Richter. FAZ. October 21. Available online: https: / / www.faz.net/aktuell/politik/ausland/attentat-auf-samuel-paty-sieben-vor-anti-terror-richter-17012210.html (accessed on 18 November 2020).

Ghosh, Ratna, W. Y. Alice Chan, Ashley Manuel, and Maihemuti Dilimulati. 2016. Can education counter violent religious extremism? Canadian Foreign Policy Journal 23: 117-33. [CrossRef]

Goldberg, David Theo. 2006. Racial Europeanization. Ethnic and Racial Studies 29: 331-64. [CrossRef]

Grillo, Ralph. 2004. Islam and transnationalism. Journal of Ethnic and Migration Studies 30: 861-78. [CrossRef]

Gutton, Philippe. 2015. Adolescence et Djihadisme. Paris: L'Esprit du Temps.

Hancock, Claire. 2008. Spatialities of the secular: Geographies of the Veil in France and Turkey. European Journal of Women's Studies 15: 165-79. [CrossRef]

Hancock, Claire. 2015. 'The Republic is lived with an uncovered face' (and a skirt): (Un)dressing French citizens. Gender, Place E Culture 22: 1023-40.

Hancock, Claire, and Virginie Mobillion. 2019. "I want to tell them, I'm just wearing a veil, not carrying a gun!” Muslim women negotiating borders in femonationalist Paris. Political Geography 69: 1-9. [CrossRef]

Hauser, Jonathan. 2021. Education, secularism, and illiberalism: Marginalisation of Muslims by the French state. French Cultural Studies 32: 149-62. [CrossRef]

Higgins, Andrew, and Kimiko de Freytas-Tamura. 2016. In Brussels Bombing Plot, a Trail of Dots Not Connected. The New York Times. March 27. Available online: https:/ / www.nytimes.com/2016/03/27/world/europe/in-brussels-bombing-plot-a-trail-of-dotsnot-connected.html (accessed on 28 September 2021).

Jackson, Richard. 2014. Constructing Enemies: 'Islamic Terrorism' in Political and Academic Discourse. Government and Opposition 42: 394-426. [CrossRef]

Jansen, Yolande. 2006. Laïcité, or the politics of republican secularism. In Political Theologies. Edited by Hent de Vries H and Lawrence E. Sullivan. New York: Fordham University Press, pp. 475-93. 
Jikeli, Gunter. 2018. Discrimination against Muslims and Antisemitic Views among Young Muslims in Europe. In Antisemitism Today and Tomorrow. Global Perspectives on the Many Faces of Contemporary Antisemitism. Edited by Mikael Shainkman. Boston: Academic Studies Press, pp. 101-24.

Jobard, Fabien. 2017. Der Notstand in Frankreich-Tragödie oder Farce? Zur Geschichte der Anwendung des Notstandsgesetzes in Frankreich. Apri. Available online: https:/ / www.rosalux.de/publikation/id/14771/ (accessed on 2 October 2021).

Käsehage, Nina. 2017. Dschihad als Ausweg. Warum Tschetschenische Frauen in den Krieg ziehen und Deutsche Kämpferinnen Ihnen Folgen. [Jihad as exit. Why Chechen women turn to jihad and German female fighters follow them]. Springe: Zu Klampen.

Käsehage, Nina. 2018. Die Gegenwärtige Salafistische Szene in Deutschland-Prediger und Anhänger, 2nd ed. [The current Salafist scene in Germany-Preachers and Adherents]. Berlin: LIT.

Käsehage, Nina. 2021. Prevention of Radicalization in Western Muslim Diasporas. In Handbook of Terrorism Prevention and Preparedness. chp. 11. Edited by Alex P. Schmid. The Hague: ICCT Press, pp. 304-73. [CrossRef]

Kelly, Michael. 2017. Laïcité and atheism in France. French Cultural Studies 28: 111-22. [CrossRef]

Kepel, Gilles. 1987. Les banlieues de l'Islam. Naissance d'une religion en France. [The suburbs of Islam: The birth of a religion in France]. Paris: POINTS.

Kepel, Gilles. 2005. Du Jihad à la Fitna. [From jihad to fitna]. Paris: Bayard.

Kepel, Gilles. 2012. Banlieue de la République. [Suburb of the Republic]. Paris: Gallimard.

Kepel, Gilles. 2015. Terreur dans l'Hexagone. Genèse du Djihad Francais. [Terror in France: Genesis of the French Jihad]. Paris: Gallimard.

Khosrokhavar, Fahrad. 1997. L'Islam des Jeunes [Islam of the Young]. Paris: Flammarion.

Khosrokhavar, Fahrad. 2003. Les Nouveaux Martyr d'Allah [The New Martyrs of Allah], 2nd ed. Paris: Flammarion.

Khosrokhavar, Farhad. 2013. Radicalisation in Prison: The French Case. Politics, Religion and Ideology 14: 284-306. [CrossRef]

Khosrokhavar, Farhad. 2014. Radicalisation. Paris: Éditions de la Maison des sciences de l'homme.

Khosrokhavar, Fahrad, David Bénichou, and Philippe Migaux. 2015. Le Jihadsme. Le Comprendre pour Mieux le Combattre [Jihadism: Understanding it to better combat it]. Paris: Plon.

Kienzler, Klaus. 2007. Der religiöse Fundamentalismus. Christentum-Islam-Judentum. [The religious Fundamentalism. Christianity-IslamJudaism.], 5th ed. München: C.H. Beck.

König, Jürgen. 2016. Revolution oder Radikalisierung? Frankreichs Intellektuelle streiten über Terror-Ursachen. [Revolution or radicalization? France's intellectuals argue about the causes of terrorism]. Deutschlandfunk. August 13. Available online: https: //www.deutschlandfunk.de/revolution-oder-radikalisierung-frankreichs-intellektuelle.691.de.html?dram:article_id=363033 (accessed on 2 October 2021).

Limage, Leslie J. 2000. Education and Muslim identity: The case of France. Comparative Education 36: 73-94. [CrossRef]

Lizotte, Christopher A. 2020. Laïcité as assimilation, laïcité as negotiation: Political geographies of secularism in the French public school. Political Geography 77: 1-10. [CrossRef]

Martinez, Magdalena. 2016. Loss of Identity, Radicalization, and Terrorism. Case Studies in France and Belgium. Master's thesis, University of San Francisco, San Francisco, CA, USA. Available online: https://repository.usfca.edu/thes/195/?utm_source= repository.usfca.edu\%2Fthes\%2F195\&utm_medium=PDF\&utm_campaign=PDFCoverPages (accessed on 2 October 2021).

McLaughlin, Gilbert. 2019. Penser la radicalisation politique en France [Thinking about political radicalisation in France]. Études Internationales 50: 147-60. [CrossRef]

Ménudier, Henri. 2014. Aspekte des Katholizismus in Frankreich. In Öffentliche Religion-religiöse Öffentlichkeit. Edited by Karlies Abmeier and Michael Borchard. Paderborn: Schöningh, vol. 2, pp. 201-14.

Modood, Tariq. 2005. Multicultural Politics: Racism, Ethnicity, and Muslims in Britain. Edinburgh: Edinburgh University Press.

Modood, Tariq. 2013. Multiculturalism: A Civic Idea, 2nd ed. Cambridge: Polity Books.

Modood, Tariq. 2021. Rethinking Poliatical Secularism: The Multiculturalist Challenge. Patterns of Prejudice. London: Routledge, pp. 1-11. [CrossRef]

Neumann, Peter. 2013. Radikalisierung, De-Radikalisierung und Extremismus. Aus Politik und Zeitgeschichte (APuZ) 63: 3-10.

Nilsson, Per-Erik. 2018. Unveiling the French Republic: National Identity, Secularism and Islam in Contemporary France. Studies in Critical Research on Religion. Leiden: Brill, vol. 7.

Perry, Barbara. 2013. Gendered Islamophobia: Hate Crime against Muslim Women. Social Identities 20: 74-89. [CrossRef]

Raymond, Gino G. 2009. From Islam en France to Islam de France: Contradictions of the French left's responses to Islam. Patterns of Prejudice 43: 481-96. [CrossRef]

RFI. 2020. French police shut down Paris-region mosque over teacher's murder. RFI. October 20. Available online: https: / / www.rfi.fr/en/france/20201020-french-police-shut-down-paris-region-mosque-after-teacher-s-murder-samuel-patypantin-radical-islam (accessed on 14 September 2021).

RFI. 2021. France's anti-separatism bill deemed constitutional with only minor changes. RFI. August 14 . Available online: https:/ / www.rfi.fr/en/france/20210814-france-s-anti-separatism-bill-deemed-constitutional-with-only-minor-changesislamism-secularism (accessed on 12 September 2021).

Riedel, Sabine. 2007. Zwischen “Euro-Islam” und Islamophobie. Europäische Muslime wollen partizipieren- aber vom Zwang zur Gründung von Dachverbänden profitieren oft politische Interessengruppen. Internationale Politik 9: 36-45.

Roy, Olivier. 1992. L'Échec de l'Islam Politique. [The failure of political Islam]. Paris: Seuil.

Roy, Olivier. 2005a. Islam in the west, or western Islam? The disconnect of religion and culture. The Hedgehog Review 8: 1-6. [CrossRef] 
Roy, Olivier. 2005b. La Laicité face à l'Islam. [Secularism in the face of Islam]. Paris: Stock.

Roy, Olivier. 2015. There Are More French Muslims Working for French Security Than for Al Qaeda. Huffpost. September 1. Available online: https:/ / www.huffpost.com/entry/paris-attack-muslim-cliches_b_6445582 (accessed on 21 November 2021).

Salvatore, Armando. 2013. Islam and the Quest for a European Secular Identity: From Sovereignty through Solidarity to Immunity. Politics, Religion E Ideology 14: 253-64.

Saral, Melek, and Şerif Onur Baheçecik, eds. 2020. State, Religion and Muslims. Between Discrimination and Protection at the Legislative, Executive and Judicial Levels. Muslim Minorities. Leiden: Brill, vol. 33.

Seelow, Soren. 2021. Attentats du 13 novembre 2015: Qui sont les vingt accusés du procès? Le Monde. September 8. Available online: https:/ / www.lemonde.fr/societe/article/2021/09/08/qui-sont-les-vingt-accuses-du-proces-des-attentats-du-13 -novembre-2015_6093806_3224.html (accessed on 28 September 2021).

Sèze, Romain. 2008. For a Visible Islam? The Emergence of a Protest Speech in French Mosques. In The Imamate in Western Europe. Developments, Transformations and Institutional Challenges. Edited by Mohammed Hashas, Jan Jap Ruiter and Niels Valdemar Vinding. Amsterdam: Amsterdam University Press, pp. 255-77.

Sèze, Romain. 2015. Leaders musulmans et fabrication d'un "Islam civil" en France. Confluences Méditerranén 95: 43-58. [CrossRef]

Sèze, Romain. 2019a. Les États Européens face aux Militandimes Violents. Dynamiques d'escalade et de Déescalade. Paris: Coll. Violence Radicales Militantes.

Sèze, Romain. 2019b. Prévenir la violence Dihadiste. Les Paradoxes d'un modèle Sécuritaire. Paris: Seuil.

Teeple Hopkins, Carmen. 2015. Social reproduction in France: Religious dress laws and laïcité. Women's Studies International Forum 48: 154-64. [CrossRef]

The New York Times. 2015. Unraveling the Connections Among the Paris Attackers. The New York Times. November 15. Available online: https:/ / www.nytimes.com/interactive/2015/11/15/world/europe/manhunt-for-paris-attackers.html?action=click\& contentCollection $=$ World\&region $=$ Footer $\&$ module $=$ WhatsNext\&version $=$ WhatsNext\&contentID $=$ WhatsNext\&moduleDetail $=$ undefined\&pgtype=Multimedia (accessed on 28 September 2021).

Thomson, David. 2016. Les Revenants, ils Etaient Partis Faire le Jihad, Ils sont de Retour en France. [The Revenants: They Had Gone to Jihad, They Are Back in France]. Paris: Seuil.

Tibi, Bassam. 2009. Euro-Islam: Die Lösung eines Zivilisationskonfliktes. Darmstadt: WBG.

Van der Made, Jan. 2021. France's parliament approves anti-separatism bill against Islamist extremism. RFI. July 24. Available online: https:/ / www.rfi.fr/en/france/20210724-france-s-parliament-approves-anti-separatism-bill-against-islamist-extremism (accessed on 30 September 2021).

Vanparys, Nathalie, Dirk Jacobs, and Corinne Torrekens. 2013. The impact of dramatic events on public debate concerning accommodation of Islam in Europe. Ethnicities 13: 209-28. [CrossRef]

Voltaire. 1764. Tolérance. Dictionnaire Philosophique. Available online: https:Classes.bnf.fr/laicite/anthologie/03.htm (accessed on 1 October 2021).

Weill, Nicolas. 2006. What's in a scarf? The debate on laïcité in France. French Politics, Culture E Society $24:$ 59-73.

Werbner, Pnina. 2007. Veiled interventions in pure space: Honour, shame and embodied struggles among Muslims in Britain and France. Theory, Culture $\mathcal{E}$ Society 24: 161-86.

Yeung, Peter. 2021. France's controversial 'separatism' bill: Seven things to know. Al Jazeera. February 15. Available online: https:/ / www.aljazeera.com/news/2021/2/15/frances-controversial-separatism-bill-explained (accessed on 30 September 2021). 